\title{
ANALISIS KANDUNGAN BIOMASSA DAN KARBON TERSIMPAN (Carbon Stock) PADA PSP (Plot Sampling Parmanent) HUTAN NEGERI SOYA KOTA AMBON.
}

\author{
${ }^{1}$ Yulianus. D. Komul*, ${ }^{2}$ Gun Mardiatmoko, Rohny S. Maail \\ 1, 2, ${ }^{3}$ Program Studi Manajemen Hutan, Pascasarjana Universitas Pattimura Ambon \\ Jl. Dr.Ir. M. Latumeten, Kampus PGSD - Ambon 57131 \\ *Penulis Korespondensi Email : komulyulianus@yahoo.co.id
}

Diterima : 16 Mei $2016 \quad$ Disetujui : 25 Agustus 2016

\begin{abstract}
Intisari
Cadangan karbon pada dasarnya merupakan banyaknya karbon yang tersimpan pada vegetasi, biomas lain dan di dalam tanah. Upaya pengurangan konsentrasi GRK di atmosfer (emisi) adalah dengan mengurangi pelepasan $\mathrm{CO}_{2}$ ke udara. Untuk itu, maka jumlah $\mathrm{CO}_{2}$ di udara harus dikendalikan dengan jalan meningkatkan jumlah serapan $\mathrm{CO}_{2}$ oleh tanaman sebanyak mungkin dan menekan pelepasan emisi serendah mungkin. Jumlah cadangan karbon tersimpan ini perlu diukur sebagai upaya untuk mengehui besarnya cadangan karbon pada sebuah ekosistem hutan sebagai upaya untuk penurunan emisi karbon dan efek yang merugikan. Kegiatan Penelitian telah dilaksanakan pada bulan September 2015. Lokasi PSP (Plot Sampling Parmanent) yang telah ditetapkan pembangunannya mulai tahun 2012 sebagai lokasi penelitian berada pada petuanan hutan Negeri Soya yang masuk dalam kawasan Hutan Lindung Gunung Sirimau dengan metode pengukuran dan perhitungan kandungan biomassa dan karbon tersimpan (Carbon Stock) mengacu pada Standar Nasional Indosesia (SNI):7724 Tahun 2011 tentang Pengukuran dan Penghitungan Cadangan Karbon. Secara keseluruhan untuk hutan primer dan starat hutan sekunder jumlah populasi tegakan 409 individu yang terdiri atas tingkat Pohon sebanyak 67, tingakat tiang 19, Sapihan/pancang sebanyak 208 populasi, dan tingkat Semai sebanyak 105 populasi. Jumlah kandungan biomassa untuk Untuk strata hutan primer kandungan biomassa total berkisar antara 510, 3590 ton/ha - 786,6950 ton/ha dengan rata-rata kandungan biomassa berkisar pada 640,4733 ton/ha. Untuk starata hutan sekunder kandungan biomassa total berkisar antara 210,1608 ton/ha - 436,6976 ton/ha dengan rata-rata berkisar pada 289,4509 ton/ha. Jumlah Ctersimpan pada strata hutan primer berkisar antara 239.9190 ton/ha

- 369.0228 ton/ha dengan rata-rata 301.1112ton/ha. Untuk strata hutan sekunder, jumlah karbon tersimpan berkisar antara 88.9805 ton/ha - 139.7868 ton/ha dengan rata-rata 110.1785 ton/ha.
\end{abstract}

Kata Kunci : Desa soya, Kandungan biomassa, Karbon, Plot sampel permanen

\begin{abstract}
Carbon stocks while amount of carbon stored on vegetation, other biomass and soil. Effort to reduce greenhouse gas concentrations at atmosphere (emissions) ito reduce CO2 into air. Amount of CO2 on air must be controlled by increasing of $\mathrm{CO} 2$ by plants as much as possible and reducing release of emissions as low as possible. Carbon stored reserves should be measured as attempt to carbon stocks in forest to decrease carbon emissions and adverse effects. Research do in September 2015 at parmanent sampling plot on 2012 at Soya included Mount Sirimau. Method of biomass and carbon stocks on Measurement and Calculation of Carbon Stock overall primary forests and secondary forests consist of 409. Total biomass content for For strata of primary forest biomass is 510 with 3590 tons / ha - 786.6950 tons / ha with average content of biomass at 640.4733 tons/ ha. .At secondary forest is 210.1608 tons / ha to 436.6976 tons / ha with 289.4509 tons / ha. Carbon-stored at primary forest is 239.9190 tons / ha to 369.0228 tons / ha with 301.1112 tons / ha. On secondary forest amount of carbon stored is 88.9805 tons / ha to 139.7868 tons / ha and 110.1785 tons / ha.
\end{abstract}

Keywords: Carbon, Content biomass, Plot sampling parmanent, Soya district 


\section{PENDAHULUAN}

Karbon merupakan salah satu unsur terpenting dalam kehidupan sehari-hari dan berperan sebagai pembentuk gas rumah kaca (GRK). Di sektor kehutanan, kontribusi terhadap GRK terutama disebabkan oleh gas karbon dioksida $\left(\mathrm{CO}_{2}\right)$. Gas Rumah Kaca yang mengandung unsur karbon adalah gas metan $\left(\mathrm{CH}_{4}\right)$, Hidro Fluoro Carbon (HFC), dan PFC. Konsentrasi gas-gas ini dalam skala global secara kumulatif dipengaruhi langsung oleh aktivitas manusia, meskipun gas-gas tersebut juga terjadi secara alamiah.

Konteks perubahan iklim, hutan dapat berperan baik sebagai sink (penyerap/penyimpan karbon) maupun Source (pengemisi karbon). Deforestasi dan degradasi meningkatkan Source, sedangkan aforestasi, reforestasi dan kegiatan pertanaman lainnya serta konservasi hutan meningkatkan sink. Dalam pengelolaan hutan lestari penyerapan karbon merupakan jasa yang dapat diberikan oleh sektor kehutanan. Sebaliknya kegiatan kehutanan yang berhubung-an dengan serapan karbon akan mendukung pengelolaan hutan lestari. Misalnya kegiatan aforestasi, reforestasi dan mencegah deforestasi.

Cadangan karbon pada dasarnya merupakan banyaknya karbon yang tersimpan pada vegetasi, biomas lain dan di dalam tanah. Upaya pengurangan konsentrasi GRK di atmosfer (emisi) adalah dengan mengurangi pelepasan $\mathrm{CO}_{2}$ ke udara. Untuk itu, maka jumlah $\mathrm{CO}_{2}$ di udara harus dikendalikan dengan jalan mening-katkan jumlah serapan $\mathrm{CO}_{2}$ oleh tanaman sebanyak mungkin dan menekan pelepasan emisi serendah mungkin. Jadi, mempertahankan keutuhan hutan alami, menanam pepohonan pada lahan-lahan pertanian dan melindungi lahan gambut sangat penting untuk mengurangi jumlah $\mathrm{CO}_{2}$ yang berlebihan di udara (Hairiah, 2007).

Jumlah cadangan karbon tersimpan ini perlu diukur sebagai upaya untuk mengehui besarnya cadangan karbon pada saat tertentu dan perubahannya apabila terjadi kegiatan yang manambah atau mengurangi besar cadangan. Dengan mengukur, dapat diketahui berapa hasil perolehan cadangan karbon yang terserap dan dapat dilakukan sebagai dasar jual beli cadangan karbon. Dimana negara maju atau Negara industry mempunyai kewajiban untuk memberi kompensasi kepada Negara, lembaga atau siapapun yang dapat mengurangi emisi atau meningkatkan serapan.

Penelitian mengenai karbon tersimpan perlu dilakukan untuk mengetahui perubahan karbon tersimpan di suatu kawasan dalam hubungannya dengan konversi penggunaan lahan. Berdasarkan pada fungsi hutan sebagai penyerap karbon, informasi mengenai jumlah karbon yang disimpan (stok karbon) pada kurun waktu tertentu pada suatu kawasan hutan di Indonesia secara keseluruhan, maupun Maluku secara khusus menjadi penting. Informasi tentang besarnya karbon yang dapat diserap pada suatu ekossitem hutan dapat diperoleh dengan cara konvensional akan tetapi cara ini membutuhkan waktu lama, biaya besar dan belum mampu mengimbangi permintaan informasi yang cepat dan akurat apabila dalam skala intensitas yang lebih tinggi.

Indonesia secara umum, proyek pengelolaan Sumber Daya Alam untuk penyimpanan karbon (FORMACS) yang didanai oleh CIDA dan diimplementasikan oleh CARE Internatio-nalIndonesia merupakan salah satu contoh proyek ADEF. Proyek FORMACS memfokuskan pada pengelolaan sumber daya hutan yang telah ada sebagai penyerap dan penyimpan karbon dengan mengadopsi program pengelolaan berba-sis masyarakat (Noordwijk et al., 2002).

Maluku memulai kegiatan pengukuran dan perhitungan penyerapan karbon (Carbon stok) melalui impelmentasi REDD+ yang diselenggarakan oleh Kementerian Kehutanan Pusat Penelitian dan Pengembangan Perubahan Iklim dan Kebijakan (PUSPIJAK) dengan pembangunan PSP (Plot Sampling Parmanent) pada beberapa tipe hutan di Maluku yang implementasinya difokuskan pada Pulau seram (PSP Hutan produksi Mornaten yang kedepannya dijadikan sebagai KPHP Mornaten) dan Pulau Ambon (PSP Hutan Lindung Negeri Soya yang telah ditetapkan sebagai KPHL Unit XIV Kota Ambon) yang kemudian dilanjutkan pada tahun 2013 dengan kegiatan monitoring/pemantauan dan evaluasi PSP (Plot Sampling Parmanent).

Berdasarkan latar belakang yang telah dipaparkan maka diperlukan pengukuran untuk mengetahui nilai kandungan biomassa dan karbon tersimpan tahun 2015 sebagai informasi yang akurat tentang penyerapan karbon dari sektor kehutanan untuk mendukung berbagai kajian di masa akan datang dengan judul kajian" Analisis Kandunagn Biomassa dan Karbon Tersimpan Pada PSP (Plot Sampling Parmanent) Hutan Negeri Soya Kota Ambon".

Informasi cadangan karbon di berbagai tipe hutan dan ekosistem diharapkan mampu menjadi dasar pertimbangan para pihak untuk menentu-kan keputusan teknis lainnya, seperti: (1) estimasi emisi yang akan dihasilkan apabila hutan atau 
pohon tertentu ditebang, dan (2) jenis vegetasi yang akan ditanam sebagai upaya peningkatan serapan karbon. Selain itu kegiatan monitoring dan evaluasi tentang pengukuran karbon dilakukan untuk memperoleh informasi tentang perubahan biomassa serta tutupan kawasan hutan yang berdampak pada upaya penurunan emisi karbon akan datang.

Sesuai dengan hal tersebut, maka dapat dirumuskan masalah sebagai indikator pelaksanaan penelitian yang mengacu pada perhitungan tingkat perubahan biomassa yang berdampak pada kandungan karbon tersimpan yang terjadi pada Plot Sampling Parmanent (PSP) Hutan Negeri Soya Kota Ambon Provinsi Maluku adalah berapa Nilai kandungan biomassa dan karbon tersimpan (Carbon Stock) yang diperoleh dari proses pengukuran tahun 2015 Pada PSP (Plot Sampling Parmanent) Hutan Negeri Soya Kota Ambon. Tujuan dari penelitian yang telah dilakukan adalah mengetahui jumlah kandungan biomassa dan karbon tersimpan (Carbon Stock) pada pengukuran tahun 2015 Pada PSP (Plot Sampling Parmanent) Hutan Negeri Soya Kota Ambon.

\section{METODE PENELITIAN}

\section{Waktu dan Lokasi Penelitian}

Kegiatan Penelitian telah dilaksanakan pada bulan September 2015. Lokasi PSP (Plot Sampling Parmanent) yang telah ditetapkan pembangunannya mulai tahun 2012 sebagai lokasi penelitian berada pada petuanan hutan Negeri Soya yang masuk dalam kawasan Hutan Lindung Gunung Sirimau yang dalam perkem-bangannya kawasan Hutan Lindung Gunung Sirimau Kota Ambon disahkan menjadi kawasan Kesatuan Pengelolaan Hutan Lindung (KPHL) Unit XIV Negeri Soya Kota Ambon berdasarkan Kepmenhut RI No. 66/MENHUT-II/2010 dengan luas \pm 10.964 Ha. (data KPH Tahun 2014). Jika dikaji berdasarkan potensi vegetasi yang terkandung maka lokasi penelitian terdiri atas dua tipe hutan yakni hutan primer dan sekunder dan masing-masing tipe hutan diwakili oleh 3 plot pengamatan dengan ukuran masing-masing plot $20 \mathrm{~m}$ x $20 \mathrm{~m}$ atau $400 \mathrm{~m}^{2}$ yang kemudian dilakukan pembagian sesuaikan dengan kebutuhan data yang akan diambil yaitu untuk tingkat permudaan (Tiang) $10 \mathrm{~m} \times 10 \mathrm{~m}$ atau $100 \mathrm{~m}^{2}$, (Sapihan) $5 \mathrm{~m} \mathrm{x}$ $5 \mathrm{~m}$ atau $25 \mathrm{~m}^{2}$ dan (Semai) $2 \mathrm{~m} \times 2 \mathrm{~m}$ atau $4 \mathrm{~m}^{2}$ serta untuk lokasi pengambilan sampel Tanah yang disesuaikan dengan ukuran plot untuk penguku-ran pohon dan tingkat permudaan.

\section{Alat dan Objek Penelitian}

Peralatan yang digunakan dalam penelitian antara lain: Phiband, Meter dan Jangka Sorong, Clinometer, Haga Meter, Timbangan gantung $50 \mathrm{~kg}$, Soil Tester, Kompas dan GPS, Neraca digital dengan ketelitian 0,5 $\%$, Oven, Gergaji kecil, Gunting Stek, Karung, Cangkulng, Parang, Sekop, Oven, Tally sheet dan wadah contoh serta camera digital.

Objek atau Sumber yang ditetapkan sebagai indikator dalam penelitian yaitu data pengukuran dilapangan berupa vegetasi Penutup tanah (pohon, tiang, sapihan, semai dan tumbuhan bawah), Nikromasa (Kayu mati dan serasah) serta bahan organik tanah yang dari keselu-ruhannya kemudian diambil sampel untuk dilakukan pengujian di laboratorium.

\section{Teknik Pengambilan Data Cadangan Karbon.}

1. Penempatan dan pembuatan permanen sample plot (PSP).

Penempatan PSP dilakukan secara purposive sampling dengan mengacu pada peta tutupan lahan pulau Seram dan Ambon. Bentu PSP dilapangan adalah berbentuk persegi dengan ukuran $20 \mathrm{~m}$ x $20 \mathrm{~m}$ (Gambar 1).

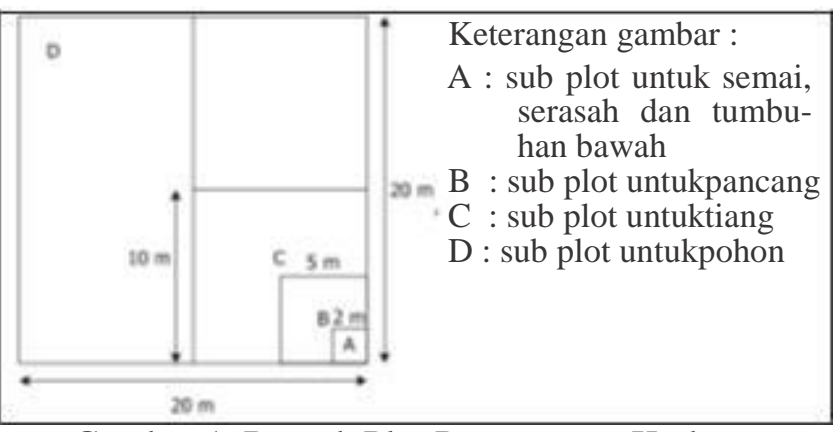

Gambar 1. Bentuk Plot Pengamatan Karbon

2. Pengukuran Biomassa dan Karbon Terimpan.

Untuk pengukuran Kandungan Biomassa

dan Karbon tersimpan (Carbon Stock) pada penelitian ini, dilakukan dengan mengacu pada mengacu pada Standar Nnasional Indosesia (SNI) : 7724 Tahun 2011.

\section{Penghitungan Kandungan Biomassa}

1. Penghitungan Biomassa diatas Permukaan Tanah Dengan Metode Allometrik

Persamaan allometrik biomassa di atas permukaan tanah yang digunakan adalah Siregar dan Dharmawan (2009) dalam Arifanty dkk (2014) atau menurut Litbang Kehutanan Tahun 2010 sedangkan untuk membandingkan hasil yang diperoleh oleh Litbang Kehutanan (2010), 
maka digunakan beberapa persamaan diantaranya untuk dan; Chave (2005) untuk hutan tipe lembab; dan Ketterings (2001) untuk hutan sekunder campuran digunakan untuk menduga biomassa di atas permukaan tanah. Persamaan alometrik yang dikembangkan oleh Siregar dan Dharmawan (2009), Chave (2005), Ketterings (2001) adalah sebagai berikut:

a. Pendugaan biomassa di atas permukaan tanah untuk hutan lahan kering berdasarkan hasil penelitian yang dilakukan oleh Siregar dan Dharmawan (2009) atau menurut Litbang Kehutanan (2010) dengan menggunakan rumus.

Keterangan

$$
\mathrm{Y}=1 / 4 \prod \times(\mathrm{DBH})^{2,2234}
$$

Y : Biomasa total $(\mathrm{Kg})$

1/4 П: 97,7

DBH : Diameter setinggi dada pada ketingian 1,3 meter

b. Penghitungan biomassa dengan persamaan Chave (2005) untuk hutan tipe lembab dengan rumus :

Keterangan

$$
\mathrm{Y}=0,0509 . \mathrm{DBH} \cdot \mathrm{T}
$$

Y : Biomasa total $(\mathrm{Kg})$

DBH : Diameter setinggi dada pada ketingian 1,3 meter

$\mathrm{T} \quad$ : Tinggi pohon (m)

atau menggunakan rumus

$$
\begin{aligned}
& \mathrm{AGB}_{\mathrm{est}}=0,0509 \times \prod \mathrm{D}^{2} \mathrm{H}
\end{aligned}
$$

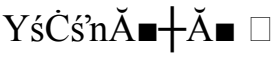

$$
\begin{aligned}
& \text { ! D. est : Biomassa Total (kg) } \\
& \mathrm{H}: \text { Tinggi Pohon } \\
& \mathrm{D}^{2} \quad \text { : Diameter setinggi dada } \\
& \Pi \quad \text { : Berat jenis kayu }
\end{aligned}
$$

c. Penghitungan biomassa permukaan dengan persamaan Ketterings dkk (2001) dengan menggunakan rumus.

$$
\begin{aligned}
& B=0,11 * \rho^{*}(D)^{2,62} \prod
\end{aligned}
$$

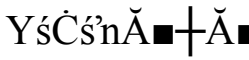

$$
\begin{aligned}
& \text {. : Biomassa (kg/pohon) } \\
& \text { D : Diameter setinggi dada }(\mathrm{cm}) \\
& \mathrm{P} \text { : massa jenis pohon atau berat jenis } \\
& \left(\mathrm{kg} / \mathrm{m}^{3}\right)
\end{aligned}
$$

2. Penghitungan Kandungan Biomassa dibawah Permukaan Tanah

Pendugaan biomassa karbon dibawah permukaan tanah (Akar) dapat dihitung dengan menggunakan rumus sebagai berikut.

$$
\mathrm{Bbp}=\mathrm{NAP} \times \mathrm{Bap}
$$

\section{Keterangan}

Bbp : Biomassa di bawah permukaan tanah $(\mathrm{kg})$

NAP : Nilai nisbah akar pucuk

Bap : Nilai biomassa di atas permukaan $(\mathrm{kg})$

3. Perhitungan Bahan Organik Serasah, Nikromassa (Kayu Mati Dan Pohon Mati)

$$
\begin{aligned}
& \text { Bo }=\frac{\text { Bbt x Bks }}{. \mathrm{L}^{\prime} \ell} \\
& \text { YśĊ́n’ Ă } \\
& \text {. - : Berat bahan organik }(\mathrm{kg}) \\
& \text { Bks : Berat kering contoh }(\mathrm{kg}) \\
& \text { Bbt : Berat basah total (kg) } \\
& \text { Bbs : Berat basah contoh }(\mathrm{kg})
\end{aligned}
$$

\section{Penghitungan Karbon}

1. Perhitungan Cadangan Biomassa dan Karbon diatas Permukaan Tanah dan Bawah Permukaan Tanah.

$$
\mathrm{Cb}=\mathrm{B} \times \mathrm{C}_{\text {organik }}
$$

Keterangan

$\mathrm{C}_{\mathrm{b}} \quad$ : Kandungan karbon dari biomasa $(\mathrm{Kg})$

B : Total biomasa $(\mathrm{Kg})$

$\% \mathrm{C}_{\text {organik }}$ : Nilai persen karbon $(0,47)$

2. Penghitungan Karbon Bahan Organik Mati Serasah dan Nikromassa (Kayu Mati Dan Pohon Mati)

Keterangan $\mathrm{Cm}=\mathrm{Bo} \times \% \mathrm{C}$ organik

$\mathrm{Cm}$ : Kandungan karbon bahan organik mati, dinyatakan dalam $\mathrm{Kg}$

Bo :Total biomassa/bahan organik, dinyatakan dalam $\mathrm{Kg}(\mathrm{kg})$;

$\% \mathrm{C}_{\text {organik: Nilai persentase kandungan }}$ karbon, sebesar 0,47

3. Perhitungan Karbon Tanah

$$
\mathrm{Ct}=\mathrm{Kd} \times \rho \times \% \mathrm{C}_{\text {organik }}
$$


Keterangan

$\mathrm{Ct}$ : Kandungan karbon tanah $\left(\mathrm{gr} / \mathrm{cm}^{2}\right)$

$\mathrm{Kd}$ : Kedalaman contoh tanah $(\mathrm{Cm})$

$\rho \quad$ : Kerapatan lindak $\left(\mathrm{gr} / \mathrm{cm}^{2}\right)$

$\% \mathrm{C}_{\text {organik: Nilai persentase kandungan }}$ karbon, sebesar 0,47

\section{Perhitungan Cadangan Total}

1. Perhitungan Cadangan Total Per Hektar

Untuk Biomassa diatas Permukaan Tanah.

$$
C n=\frac{\text { Cx }}{1000} \quad \frac{1000}{1 \text { plot }}
$$

Keterangan

$\mathrm{C}_{\mathrm{n}}$ : Kandungan karbon per hektar pada masing-masing carbon pool pada tiap plot (ton/ha)

$\mathrm{C}_{\mathrm{X}}$ : Kandungan karbon pada masing-masing carbon pool pada tiap plot $(\mathrm{kg})$

$1_{\text {plot }}$ : Luas plot pada pool dinyatakan dalam meter persegi $\left(\mathrm{m}^{2}\right)$

2. Penghitungan Kandungan Karbon Organik

Tanah Per Hektar.

Keterangan

$$
\mathrm{C}_{\mathrm{tanah}}=\mathrm{C}_{\mathrm{t}} \times 1000
$$

$\mathrm{C}_{\text {tanah }}$ : Kandungan karbon organik tanah per hektar (ton/ha);

$\mathrm{C}_{\mathrm{t}}$ : Kandungan karbon tanah $(\mathrm{g} / \mathrm{cm})^{2}$

100 : Faktor konversi dari g/cm2 ke ton/ha

3. Penghitungan Cadangan Karbon Total Dalam Plot

$$
\underset{\text { plot }}{\mathrm{C}}=(\underset{\text { bap }}{\mathrm{C}}+\underset{\text { bbp }}{\mathrm{C}}+\underset{\text { serasah }}{\mathrm{C}}+\underset{\text { km }}{\mathrm{C}}+\underset{\text { pm }}{\mathrm{C}}+\underset{\text { tanah }}{\mathrm{C}})
$$

\section{Keteragan}

$\mathrm{C}_{\text {plot }}$ : Total kandungan karbon pada (ton/ha)

$\mathrm{C}_{\text {bap }}$ : Total kandungan karbon biomassa atas permukaan per hektar pada plot (ton/ha)

$\mathrm{C}_{\text {serasah }}$ : Total kandungan karbon biomassa serasah per hektar (ton/ha)

$\mathrm{C}_{\mathrm{km}}$ : Total kandungan karbon kayu mati per hektar pada plot (ton/ha)

$\mathrm{C}_{\mathrm{pm}}$ : Total kandungan karbon kayu mati per hektar pada plot,(ton/ha);

$\mathrm{C}_{\text {tanah }} \quad$ : Total kandungan karbon tanah per hektar pada plot
4. Penghitungan Cadangan Karbon Total Dalam Stratum.

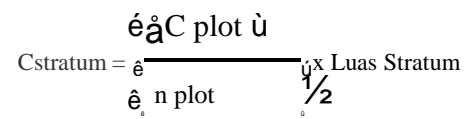

Keterangan

Cstratum : Total cadangan karbon dalam stratum

nplot : Kandungan karbon gram $\left(\mathrm{g} / \mathrm{cm}^{2}\right)$

Cplot : Total kandungan karbon per hektar pada plot dalam stratum

Luas stratum : D inyatakan dalam hektar (ha).

5. Penghitungan Cadangan Karbon Total Dalam Suatu Areal.

$$
\mathrm{C}_{\text {total }}=\sum \mathrm{C}_{\text {statum }}
$$

Keterangan

$\mathrm{C}_{\text {total }}$ : Cadangan karbon dalam suatu areal, dinyatakan dalam ton

$\mathrm{C}_{\text {stratum }}$ : Total cadangan karbon dalam stratum, dinyatakan dalam ton.

\section{HASIL DAN PEMBAHASAN}

\section{Perhitungan Kandungan Biomassa Atas Pemukaan}

Biomassa atas permukaan adalah semua material hidup di atas permukaan, termasuk bagian dari kantong karbon ini adalah batang, tunggul, cabang, kulit kayu, biji dan daun dari vegetasi baik dari strata pohon maupun dari strata tumbuhan bawah di lantai hutan. Sutaryo, D. 2009). Selanjutnya dijelaskan biomassa pohon atau biomassa permukaan merupakan salah satu sumber karbon yang sangat penting pada ekosistem hutan, karena sebagian besar karbon hutan berasal dari biomasa pohon. Pohon merupakan proporsi terbesar penyim panan $\mathrm{C}$ di daratan. Hasil yang diperoleh untuk pengukuran kandungan biomassa atas permukaan pada tahun 2015 secara keseluruhan untuk kedua tipe hutan adalah dirinci sebagai berikut ; jumlah populasi keseluruhan yaitu 409 individu, terbagi atas tingkat Pohon 67 individu, tingakat Tiang sebanyak 19 individu, Sapihan/pancang sebanyak 208 individu, dan tingkat Semai sebanyak 105 individu.

Dijabarkan melalui analisis komposisi floristik yang dilakukan, diperoleh data bahwa kisaran diameter tegakan untuk setiap individu pohon yang ditemukan pada lokasi penelitian adalah berkisar antara diameter $0,1 \mathrm{~cm}-150,2$ $\mathrm{cm}$. jenis tanaman dan jumlah pohon terbanyak ditemukan pada plot hutan primer dengan 
kerapatan tinggi di tingkat dan kisaran diameter yang sering ditemukan (Dominan) yaitu pada tingkat pertumbuhan Sapihan/Pancang sebanyak 19 jenis yang terdiri atas 113 individu. Jenisjenis yang dominan ditemukan adalah Kayu Merah (Eugenia cumini), Taheru (Eugenia sp) dan Pala Hutan (Myristica sp).

Perhitungan kandungan biomassa atas permukaan yang dilakukan dengan menggunakan metode allometrik (Chaves 2005, Khetering 2001 dan Libang Kehutanan 2010) menunjukan hasil yang hampir mirip jika dikaji dari nilai kandungan biomassa yang diperoleh. Kandungan biomassa total untuk tipe hutan primer berkisar antara 371,6892 ton/ha - 572,4099 ton/ha, dan untuk strata hutan sekunder berkisar antara
153,1594 ton/ha - 318,6353 ton/ha. Untuk lebih jelas di tampilkan pada tabel 2 .

Kandungan biomassa tertinggi untuk tingkat Pohon, tiang dan sapiham berada pada plot 1 hutan primer dengan jumlah 572.0588 ton/ha, untuk tingkat semai dan tumbuhan bawah berada pada plot 1 hutan primer dengan jumlah 0.5558 ton/ha dan 0.0153 ton/ha. secara keseluruhan kandungan biomassa strata hutan primer lebih tinggi bila dibandingkan dengan strata hutan sekunder dengan kandungan biomassa tertinggi yaitu 572.4099 ton/ha.

Tingkat kerapatan vegetasi pada hutan primer lebih tinggi jika dibandingkan dengan strata hutan sekunder. Begitu juga ukuran diameter pohon maupun tingginya yang

Tabel 1. Komposisi Floristik Tegakan Pada PSP (Plot Sampling Parmanent)

\begin{tabular}{llcccl}
\hline Tipe Vegetasi & Karbon Pool & $\begin{array}{c}\text { Jumlah } \\
\text { Jenis }\end{array}$ & $\begin{array}{c}\text { Jumlah } \\
\text { Pohon }\end{array}$ & DBH $(\mathrm{cm})$ & Jenis Dominan \\
\hline Hutan & Pohon & 7 & 30 & $20-84,2$ & Meterosideros \\
Sekunder & & 7 & 13 & $10-19,5$ & Ganua motleyana \\
& Tiang & 13 & 106 & $1,1-10$ & Eugenia sp \\
& Sapihan/pancang & 6 & 46 & & Ganua motleyana \\
& Semai & 10 & 37 & $20-150,2$ & Plaqium javense \\
Hutan Primer & Pohon & 5 & 6 & $10,8-19,8$ & Eugenia cumini \\
& Tiang & 19 & 113 & $1,1-7,85$ & Eugenia cumini \\
& Sapihan/Pancang & 12 & 59 & $0-1,0$ & Eugenia cumini \\
\hline
\end{tabular}

Sumber : Data Primer Setelah diolah, 2016

Tabel 2.Jumlah Kandungan Biomassa Atas Permukaan Pada Hutan Primer dan Sekunder Tahun 2015.

\begin{tabular}{|c|c|c|c|c|c|c|c|}
\hline \multirow{3}{*}{ Nomor } & \multirow{3}{*}{ Karbon Pool } & \multicolumn{6}{|c|}{ Kandungan Biomassa total (ton/ha) } \\
\hline & & \multicolumn{3}{|c|}{$\begin{array}{c}\text { Strata } \\
\text { Hutan Primer }\end{array}$} & \multicolumn{3}{|c|}{$\begin{array}{c}\text { Strata } \\
\text { Hutan Sekunder }\end{array}$} \\
\hline & & I & II & III & I & II & III \\
\hline \multicolumn{8}{|c|}{ Periode III Tahun 2015} \\
\hline 1. & $\begin{array}{l}\text { Sapihan/Tiang/ } \\
\text { Pohon }\end{array}$ & 572,0588 & 371,5264 & 456,6567 & 152,7100 & 318,4543 & 161,3210 \\
\hline 2. & Semai & 0,3358 & 0,1400 & - & 0,4081 & 0,1675 & 0,7004 \\
\hline \multirow[t]{2}{*}{3.} & Tumbuhan Bawah & 0,0153 & 0,0228 & 0,0208 & 0,0413 & 0,0135 & 0,0415 \\
\hline & Total (3) & 572,4099 & 371,6892 & 456,6775 & 153,1594 & 318,6353 & 162,0629 \\
\hline
\end{tabular}

Sumber : Data Primer Setelah diolah, 2016

ditemukan di areal strata hutan primer lebih besar dibandingkan dengan strata hutan sekunder. Hal ini mengindikasikan bahwa kandungan biomassa pada strata hutan sekunder lebih rendah.

Pada pengukuran ketiga tahun 2015 untuk tingkat semai dan sapihan sesuai dengan hasil analisis, diketahui menempati hampir seluruh plot pada kedua starat hutan kecuali pada plot 3 strata hutan primer. Kehadiran semai sapihan serta tumbuhan bawah secara keseluruhan disebabkan oleh laju pertumbuhan tegakan yang dipengaruhi oleh proses suksesi, dimana untuk 
hutan sekunder proses suksesi terjadi dengan munculnya spesies-spesies baru yang dengan kecepatan pertumbuhan tinggi serta toleransi dalam menempati ruang bahkan turut mendominasi jenis-jenis yang telah ditempati sebelumnya oleh jenis-jenis lama. Dimana nilai kandungan biomassa tingkat semai berkisar antara 0,1400 ton/ha - 0,3358 ton/ha, sedangkan pada strata hutan sekunder berkisar antara 0,1675 ton/ha 0,7004. Untuk tumbuhan bawah, jumlah kandungan biomassa pada strata hutan primer berkisar antara 0,0153 ton/ha $-0,0228$ ton/ha, sedangkan pada strata hutan sekunder berkisar antara 0,0135 ton/ha - 0,0415 ton/ha. Dengan demikian nilai kandungan biomassa tingkat semai dan tumbuhan bawah pada pengukuran 2015 mengalami peningkatan jika dibandingkan pengukuran sebelumnya.

\section{Perhitungan Kandungan Biomassa Bawah Permukaan (Akar)}

Biomassa bawah permukaan tanah, seperti yang dikutip oleh Manuri, dkk (2011) sesuai IPCC guidelines (2006) adalah semua biomassa dari akar yang masih hidup. Akar yang halus dengan diameter kurang dari $2 \mathrm{~mm}$ seringkali dikeluarkan dari perhitungan, karena sulit dibedakan dengan bahan organik mati tanah dan serasah (Annonim 2013).

Persamaan allometrik yang dikembangkan oleh Litbang Kehutanan (2010) menunjukan nilai kandungan biomassa dankarbon tersimpan bawah permukaan khusus untuk tingkat pertumbuhan pohon, tiang dan sapihan pada strata hutan sekunder adalah sebesar 233,9836 ton/ha sedangkan untuk strata hutan primer adalah sebesar dan 518,0677 ton/ha. Nilai yang diperolehpun mendekati hasil perhitungan dengan metode Chaves (2005) yang dipakai sebagai pembanding dalam perhitungan allometrik. Untuk tingkat pertumbuhan semai dan tumbuhan bawah, nilai cadangan karbon bawah permukaan yang diperoleh adalah 0,4721 ton/ha dan 0,0356 ton/ha untuk starta hutan sekunder 0,1760 ton/ha dan 0,0218 ton/ha untuk strata hutan primer.

\section{Perhitungan Kandungan Biomassa Serasah}

Menurut Sutaryo D., 2009 dalam bukunya yang berjudul "Penghitungan Biomassa Sebuah Pengantar Untuk Studi Karbon dan Perdaganagn
Karbon" menyebutkan Serasah merupakan kumpulan bahan bahan organik di lantai hutan yang belumatau sedikit terdekomposisi. Bentuk asalnya masih biasa dikenali atau masih biasa mempertahankan bentukaslinya (belum hancur). Seresah meliputi bagian tanaman yang telah gugur berupa daun dan ranting - ranting yang terletak di permukaan tanah.Pendapat lain juga disampaikan oleh Manure, dkk., (2011). Serasah adalah semua biomasa mati dengan ukuran $>2$ $\mathrm{mm}$ dan diameter kurang dari sama dengan 10 $\mathrm{cm}$, rebah dalam berbagai tingkat dekomposisi. Serasah dipilah menjadi 2 kelompok, yaitu serasah halus (daun dan ranting kecil diameter $<2 \mathrm{~cm}$ ) dan serasah ranting $(2 \mathrm{~cm}<$ diameter $<10 \mathrm{~cm})$. Semua serasah yang masuk dalam plot A dicatat ketebalannya (ketinggian dari tanah) lalu ditimbang untuk mendapatkan berat total.

Sesuai dengan hasil pengukuran periode ketiga tahun 2015 yang merujuk pada metode yang dipakai dari SNI 7724 tahun 2011, besarnya jumlah kandungan biomassa serasah pada kedua strata hutan dapat disajikan lewat hasil analisis penelitian pada tabel 3 .

Kandungan biomassa serasah pada strata hutan primer berkisar antara 0,7459 ton/ha 1.36803 ton/ha dengan rata-rata kandungan biomassa serasah berada pada 1,0209 ton/ha. Sedangkan strata hutan sekunder, kandungan biomassa yang diperoleh berkisar antara 0.2253 ton/ha -0.7188 ton/ha dengan kisaran rata-rata berada pada 0,4150 ton/ha. Kandung-an biomassa serasah dari pengukuran periode ketiga tahun 2015 yang disajikan, ternyata memiliki nilai yang paling rendah bila dibanding-kan dengan hasil pengukuran dua periode sebelum-nya. Berkurangnya kandungan biomassa serasah ini disebabkan oleh beberapa faktor diantaranya cuaca dan iklim dari wilayah setempat serta potensi vegetasi yang dimiliki. Intensitas curah hujan yang tinggi serta pada pangambilan sampel untuk periode sebelumnya dilakukan tepat pada musim penghujan sehingga berpengaruh besar pada berat basah total yang dihasilkan. Pendapat yang sama pula dikemuka-kan oleh Rosita, (2011) bahwa produk-tivitas serasah juga di pengaruhi vegetasi dan curah hujan. Curah hujan mempengaruhi fisiologi vegetasi karena semakin tinggi curah hujan maka semakin rendah guguran daun, ranting, bunga dan buah pada saat curah hujan tinggi kelembaban meningkat maka 
Tabel 3. Perbandingan Jumlah Kandungan Biomassa Serasah Pada Strata

Hutan Primer Dan Sekunder Tahun 2012, 2013 dan 2015

\begin{tabular}{|c|c|c|c|c|c|c|c|c|c|c|}
\hline \multirow{3}{*}{ Nomor } & \multirow{3}{*}{ Stratifikasi } & \multicolumn{3}{|c|}{ Tahun 2012*) } & \multicolumn{3}{|c|}{ Tahun 2013*) } & \multicolumn{3}{|c|}{ Tahun 2015*) } \\
\hline & & \multicolumn{9}{|c|}{ Kandungan Biomassa Serasah (ton/ha) } \\
\hline & & $\mathrm{I}$ & II & III & $\mathrm{I}$ & II & III & $\mathrm{I}$ & II & III \\
\hline 1. & $\begin{array}{l}\text { Hutan } \\
\text { Primer }\end{array}$ & 13,0720 & 9,2408 & 3,6713 & 7,7475 & 4,0533 & 4,1260 & 0.9488 & 1.3680 & 0.7459 \\
\hline 2. & $\begin{array}{l}\text { Hutan } \\
\text { Sekunder }\end{array}$ & 0,7481 & 4,2950 & 1,7698 & 4,1058 & 2,7133 & 3,0328 & 0.7188 & 0.3009 & 0.2253 \\
\hline
\end{tabular}

Sumber : Data Primer Setelah diolah, 2015

penguapan daunakan menurun sehingga daun tetap segardan tidak mudah gugur.

Pengukuran pada periode ketiga tahun 2015, kondisi lokasi pada saat pengukuran mengalami musim pancaroba dimana peralihan antara musim hujan dan kemarau, sehingga berdampak pada kehadiran serasah yang berpengaruh pula pada ketersediaan kandungan biomassa. Disampaikan pula bahwa kehadiran serasah juga bergantung pada kondisi vegetasi atau jenis-jenis tegakan yang menempati lokasi penelitian. Jumlah jenis yang ditemukan hanya 21 jenis dan hampir dominan dalam proses pertumbuhan baik berbunga, bertunas berbuah maupuan dalam proses menggugurkan daun. Selain itu, kondisi serasah di lokasi penelitian yang merupakan areal pengambilan data yang sama pada periode sebelumnya sehingga proses fisiologis tanaman di hutan baik primer dan sekunder belum berlangsung secara baik.

\section{Perhitungan Kandungan Biomassa Nekromassa}

Hasil pengukuran dan pendugaan Nekromassa (baik pohon mati dan kayu mati) pada kedua strata hutan di lokasi penelitiandi sajikan pada tabel 4. Besarnya kandungan bahan organik baik dari kayu mati dan pohon mati (nekromassa) untuk periode pertama dan kedua memiliki nilai yang lebih besar dibandingkan pada periode ketiga tahun 2015. Dimana untuk kandungan nekromassa dari kayu mati bernilai 0 atau tidak ditemukan sama sekali. Sedangkan untuk kayu mati hanya ditemukan pada 3 plot pengamatan dari keseluruhan plot yang dilakukan penelitian.

Berkurangnya Nikromassa yang ditemu-kan disebabkan karna penelitian yang dilakukan hanya mengacu pada perubahan yang terjadi dari periodesasi pengukuran yang telah dilakukan sebelumnya, dalam hal ini penelitian sudah dilakukan sebanyak tiga kali, oleh karena itu kecendrungan nilai kandungan biomassa dari nekromassa hanya diperoleh dari data baru tanpa dilakukan perlakuan ulang untuk sampel yang telah dilakukan pengukuran pada tahun sebelum-nya. Dengan kata lain proses penelitan hanya difokuskan pada data nikromass baru yang ditemukan pada tahun 2015, atau setelah pengukuran periode kedua dilakukan.

Berdasarkan data yang disajikan pada tabel 4, jumlah kandungan bahan organik Nekromassa strata hutan primer dan sekunder untuk pohon mati adalah kosong atau tidak ditemukan. Sedangkan untuk kayu mati kandungan biomassa berkisar antara 0,0534 ton/ha $-0,0783$ ton/ha dengan rata-rata berkisar 0,06585 ton/ha untuk strata hutan sekunder dan 0,0257 ton/ha untuk strata hutan primer.

\section{Perhitungan Kandungan Karbon Organik Tanah}

Hairiah dkk, 2011 mengartikan bahan organik tanah sebagai sisa tanaman, hewan dan manusia yang ada di dalam tanah, sebagian atau seluruhnya dirombak oleh organisme tanah sehingga melapuk dan menyatu dengan tanah, dinamakan bahan organik tanah. Karbon organic tanah pada lokasi penelitian dihitung dengan mengikuti standarisasi nasional Indonesia (SNI) tahun 2011dimana untuk karbon organik tanah diperoleh dengan perkalian antara Kerapatan Lindak (Bulk Density), kedalaman contoh tanah pada saat pengambilan dan jumlah persen karbon.

B erdasarkan hasil penelitian yang dilakukan di lapangan dan dilanjutkan dengan pengujian di laboratorium, jumlah karbon 
Tabel 4. Perbandingan Hasil Perhitungan Nekromassa (Kayu Mati dan Pohon Mati) Untuk Strata Hutan Primer dan Sekunder Tahun 2012, 2013 dan 2015

\begin{tabular}{|c|c|c|c|c|c|c|c|c|c|c|}
\hline \multirow{3}{*}{ Nomor } & \multirow{3}{*}{ Stratifikasi } & \multicolumn{3}{|c|}{ Tahun $2012 *)$} & \multicolumn{3}{|c|}{ Tahun 2013*) } & \multicolumn{3}{|c|}{ Tahun $\left.2015^{*}\right)$} \\
\hline & & \multicolumn{9}{|c|}{ Kandungan Nekromassa (ton/ha) } \\
\hline & & $\mathrm{I}$ & II & III & $\mathrm{I}$ & II & III & $\mathrm{I}$ & II & III \\
\hline \multicolumn{11}{|c|}{ A. KAYU MATI } \\
\hline 1. & Hutan Primer & 0.3076 & 0.3221 & 0.9082 & 3.8616 & 10.8174 & 11.9742 & 0,0257 & - & \\
\hline 2. & $\begin{array}{l}\text { Hutan } \\
\text { Sekunder }\end{array}$ & 0.1416 & 0.9321 & - & 0.7335 & 2.0900 & 2.4457 & 0,0783 & 0,0534 & \\
\hline \multicolumn{11}{|c|}{ B. POHON MATI } \\
\hline 1. & Hutan Primer & - & 0.0275 & 0.0013 & 0.0007 & 0.0097 & - & - & - & \\
\hline 2. & $\begin{array}{l}\text { Hutan } \\
\text { Sekunder }\end{array}$ & 0.0218 & - & - & 0.0008 & - & 0.0059 & - & - & \\
\hline
\end{tabular}

Sumber : Data Primer Setelah diolah, 2015

organik tanah pada kedua strata hutan pada pengukuran ketiga tahun 2015 yang dianalisis untuk memperoleh Bulk Density dan \% C Organik tanah serta perhitungan Simpanan (Stok) Carbon tanah pada tipe hutan primer dan hutan sekunder di lokasi penelitian. Hasil analisis yang telah dilakukan yang tersaji pada tabel 5, kadungan bahan organik hutan primer Negeri Soya berkisar antara 5166,35 - 5796,65 ton/ha dengan rata-rata adalah 5463,76 ton/ha, sedangkan pada hutan sekunder berkisar antara $5347,61-6436,31$ ton/ha dengan rata-rata $=$ 6026,63 ton/ha. Kisaran stok Carbon pada 4 kedalaman tanah $(0-5 \mathrm{~cm}, 5-10 \mathrm{~cm}, 10-20 \mathrm{~cm}, 20-$ $30 \mathrm{~cm}$ ) dipengaruhi oleh dekomposisis bahan organik yang terjadi karna aktivitas vegetasi penutup tanah. Semakin meningkat pertumbuhan vegetasi diatas permukaan tanah, semakin meningkat pula kandungan karbon organik yang tersimpan didalam tanah.

Bross dan Badlock, 2008 yang dikutip oleh Seringoringo 2013, bahwa banyaknya kandung-an karbon didalam tanah disebabkan karena proses simpanan, dipengaruhi oleh sifat dan karakter dari tanah. Potensi sekuetrasi /simpanan karbon didalam tanah tergantung pada tipe/jenis

Tabel 5. Perbandingan Bulk Density, C Organik Dan Stok C Tanah pada Pengukuran Ketiga Tahun 2015.

\begin{tabular}{|c|c|c|c|c|}
\hline \multirow{2}{*}{ Tipe Hutan } & \multirow{2}{*}{$\begin{array}{c}\text { Bulk } \\
\text { Density } \\
\left(\mathrm{g} \mathrm{m}^{-3}\right)\end{array}$} & \multirow{2}{*}{$\begin{array}{c}\text { C Organik } \\
\text { Tanah } \\
(\%) \\
\end{array}$} & \multicolumn{2}{|c|}{ Stok C Tanah (Ton ha ${ }^{-1}$ ) } \\
\hline & & & Kisaran & Total \\
\hline $\begin{array}{l}\text { Hutan Primer : } \\
\text { - Plot } 1 \\
\text { - Plot } 2 \\
\text { - Plot } 3\end{array}$ & $\begin{array}{l}0,44-1,08 \\
0,54-1,29 \\
0.58-1.09\end{array}$ & $\begin{array}{c}10,16- \\
19,58 \\
7,94-19,94 \\
8,72-16,84 \\
\end{array}$ & $\begin{array}{c}1016,20-1957,55 \\
794,01-1793,84 \\
872,36-1683,92\end{array}$ & $\begin{array}{l}5796,65 \\
5428,29 \\
5166,35\end{array}$ \\
\hline $\begin{array}{l}\text { Hutan Sekunder: } \\
\text { - Plot } 1 \\
\text { - Plot } 2 \\
\text { - Plot } 3 \\
\end{array}$ & $\begin{array}{l}0,44-1.08 \\
0,54-1.29 \\
0.58-1.09\end{array}$ & $\begin{array}{l}8,45-22,50 \\
7,65-18,83 \\
9,00-23,76 \\
\end{array}$ & $\begin{array}{l}845,47-2249,90 \\
764,78-1882,71 \\
900,43-2376,19 \\
\end{array}$ & $\begin{array}{l}6295,98 \\
5347,61 \\
6436,31 \\
\end{array}$ \\
\hline
\end{tabular}


tanah diantaranya; komposisi mineral tanah, tekstur, kedalaman, Bulk Density.

Menurut (Hairiah, 2007 dalam Rosita 2011) jumlah karbon tersimpan antar lahan berbeda-beda tergantung pada keragaman dan kerapatan tumbuhan yang ada, jenis tanahnya serta cara pengelolaannya. Penyimpanan karbon suatu lahan menjadi lebih besar bila kondisi kesuburan tanahnya baik atau dengan kata lain jumlah karbon tersimpan diatas tanah (Biomassa tanaman) ditentukan oleh besarnya jumlah karbon tersimpan di dalam tanah (bahan organik tanah). Hal serupa juga di kemukakan oleh pendapat Seringoringo, 2013 bahwa kehilangan simpanan karbon organic tanah disebabkan oleh faktor-faktor; penurunan biomass (diatas dan dibawah permukaan tanah) yang dikembalikan kedalam tanah.

\section{Perhitungan Total Biomassa dan Karbon Tersimpan (Carbon Stok).}

Perhitungan cadangan karbon tegakan total dalam plot pengukuran dilakukan dengan menghitung seluruh cadangan karbon dari biomassa di atas permukaan tanah, biomassa di bawah permukaan tanah, tumbuhan bawah dan nekromas (Arifanty,. dkk 2014). Hasil analisis yang diperoleh melalui penjumlahan kandungan biomassa di atas permukaan tanah, biomassa di bawah permukaan tanah, tumbuhan bawah dan nekromasa, maka kandungan karbon tersimpan yang dimiliki oleh masing - masing plot pengamatan pada starata hutan primer dan sekunder disajikan pada tabel 6 .

$\mathrm{J}$ umlah kandungan biomassa total diperoleh dari penjumlahan kandungan biomassa setiap karbon pool pada semua plot pengamatan. Dari hasil penjumlahan kandungan biomassa untuk dalam plot pengamatan hutan primer diperoleh kandungan biomassa sebesar 510,3590 ton/ha - 786,6950 ton/ha dengan rata-rata adalah 640,4733 ton/ha dan 210,1608 ton/ha $-436,6976$ ton/ha dengan rata-rata berkisar pada 289,4509 ton/ha untuk strata hutan sekunder (Tabel 6).

Jumlah C-tersimpan pada strata hutan primer berkisar antara 782,7480 ton/ha 948,6878 ton/ha dengan rata-rata adalah 847,4876 ton/ha dan 674,5478 ton/ha - 745,3991 ton/ha dengan rata-rata berkisar pada 710,9296 ton/ha untuk strata hutan sekunder. Perbandingan jumlah karbon tersimpan (Carbon Stok) pada hutan primer dan strata hutan sekunder yang disajikan dalam bentuk diagram batang menunjukkan nilai yang berbeda pada semua karbon pool. Hasil pengukuran perode ketiga tahun 2015 menunjukkan terjadinya pertambahan jumlah Ctersimpan hampir pada semua karbon pool baik pada strata hutan primer maupun hutan sekunder, kecuali untuk serasah dan nikromassa yang mengalami pengurangan bahkan tidak terdapat pada kedua strata hutan. Hal ini diduga, penambahan biomassa serasah dan nikromassa memiliki korelasi yang sangat positif dengan umur pohon, kerapatan tajuk, serta curah hujan.

Tabel 6. Total Kandungan Biomassa dan Karbon Tersimpan

Tahun 2015.

\begin{tabular}{|c|c|c|c|c|c|c|c|c|c|c|c|c|}
\hline \multirow{3}{*}{$\begin{array}{l}\text { Tipe } \\
\text { Hutan }\end{array}$} & \multirow{3}{*}{ Plot } & \multicolumn{11}{|c|}{ Hasil Pengukuran Tahun 2015 Keseluruhan Kandungan Biomassa dan Carbon Stok } \\
\hline & & \multicolumn{2}{|c|}{$\begin{array}{l}\text { Atas Permukaan } \\
\text { (ton/ha) }\end{array}$} & \multicolumn{2}{|c|}{$\begin{array}{l}\text { Bawah Permukaan } \\
\text { (ton/ha) }\end{array}$} & \multicolumn{2}{|c|}{ Serasah (ton/ha) } & \multicolumn{2}{|c|}{$\begin{array}{l}\text { Nikromassa } \\
\text { (ton/ha) }\end{array}$} & \multirow{2}{*}{$\begin{array}{l}\text { Tanah } \\
\text { C Stok }\end{array}$} & \multicolumn{2}{|c|}{ Total (ton/ha) } \\
\hline & & Biomasa & C Stok & Biomas & C Stok & Bioms & C Stok & Biomasa & C Stok & & Biomasa & C Stok \\
\hline \multirow{3}{*}{$\begin{array}{l}\text { Hutan } \\
\text { Primer }\end{array}$} & I & 572.0588 & 269.0254 & 211.6617 & 99.5394 & 0.9488 & 0.4459 & 0.0257 & 0.0121 & 579.6650 & 784.6950 & 948,6878 \\
\hline & II & 371.5264 & 174.6432 & 137.4648 & 64.6328 & 1.3680 & 0.6430 & 0.0000 & 0.0000 & 542.8290 & 510.3592 & 782,7480 \\
\hline & III & 456.6567 & 214.6287 & 168.9830 & 79.4126 & 0.7459 & 0.3506 & 0.0000 & 0.0000 & 516.6350 & 626.3856 & 811,0269 \\
\hline \multicolumn{2}{|c|}{ Rata-rata } & 466.7473 & 219.4324 & 172.7032 & 81.1949 & 1.0209 & 0.4798 & 0.0086 & 0.0040 & 546.3763 & 640.4799 & 847,4876 \\
\hline \multirow{3}{*}{$\begin{array}{l}\text { Hutan } \\
\text { Sekunder }\end{array}$} & I & 152.7100 & 61.9787 & 56.6537 & 26.6272 & 0.7188 & 0.3378 & 0.0783 & 0.0368 & 629.5980 & 210.1608 & 674,5478 \\
\hline & II & 318.4535 & 84.2121 & 117.8889 & 55.4082 & 0.3009 & 0.1414 & 0.0534 & 0.0251 & 534.7610 & 436.6967 & 745,3991 \\
\hline & III & 161.3210 & 73.4867 & 59.9479 & 28.1755 & 0.2253 & 0.1059 & 0.0000 & 0.0000 & 643.6310 & 221.4942 & 712,8418 \\
\hline Rata-rata & & 210.8282 & 73.2258 & 78.1635 & 36.7370 & 0.4150 & 0.1950 & 0.0439 & 0.0206 & 602.6633 & 289.4506 & 710,9296 \\
\hline
\end{tabular}

Sumber : Data Primer Setelah diolah, 2015 
Semakin tinggi curah hujan maka semakin sedikit daun, ranting, bunga ataupun buah yang gugur. Begitupula dengan kerapatan tajuk, semakin rapat vegetasi maka intensitas cahaya matahari yang masuk menuju lantai hutan semakin sedikit, sehingga menghambat proses dekomposisi tumbuhan penutup lantai hutan (Anonim, 2013).

\section{KESIMPULAN}

Secara keseluruhan hutan primer dan hutan sekunder jumlah populasi tegakan 409 individu yang terdiri atas tingkat pohon sebanyak 67, tingakat Tiang 19, sapihan /pancang sebanyak 208 populasi, dan tingkat semai sebanyak 105 Populasi. Jumlah kandungan biomassa untuk Untuk strata hutan primer kandungan biomassa total berkisar antara 510, 3590 ton/ha $-786,6950$ ton/ha dengan rata-rata kandungan biomassa berkisar pada 640,4733 ton/ha. Untuk Hutan sekunder memiliki kandungan biomassa total berkisar antara 210,1608 ton/ha - 436,6976 ton/ha dengan rata-rata berkisar pada 289,4509 ton/ha. Jumlah C tersimpan pada strata hutan primer berkisar antara 239.9190 ton/ha - 369.0228 ton/ha dengan rata-rata 301.1112 ton/ha. Hutan sekunder, memiliki jumlah karbon tersimpan berkisar antara 88.9805 ton/ha - 139.7868 ton/ha dengan rata-rata 110.1785 ton/ha.

\section{DAFTAR PUSTAKA}

Andhi, I. M., 2012. Pendugaan Densitas Karbon Tegakan Hutan Alam Di Kabupaten J ayapura, $\mathrm{P}$ apua . B alai $\mathrm{P}$ enelitian Kehutanan Manokwari J1. Inamberi, Susweni Po Box 159, Manokwari 98313Papua Barat.

Anonym, 2009. Penghitungan Biomassa \& Potensi Karbon Studi Kasus : Kawasan Kelola SHK Lestari Di Tahura Wan Abburrachman DanKawasan Kelola M asyarakat D i P ekandangan, Way Seputih,Propinsi Lampung. Forest Watch Indonesia.

2011. Standar Nasional Indonesia., 77 24 : 2011. Pengukuran Dan Penghitungan Cadangan Karbon (Ground Based Forest Carbon Accounting)-Pengukuran Lapangan Untuk
Penaksiran. Badan Standardisasi Nasional. BSNGd. Manggala Wanabakti. Jakarta.

,2012, Laporan Akhir Pembangunan PSP (Plot Sampling Permanent) pada berbagai tipe hutan di Maluku (Forest

Carbon Partnership Facility (FCPF)

REDD+ Readiness Preparation oleh Program Studi Manajemen Hutan, program Pascasarjana Universitas Patimura, Ambon.

2013 Monitoring PSP (Plot Sampling Permanent) untuk mendukung system M RV stok carbon hutan dimaluku. $\mathrm{P}$ rogram $\mathrm{S}$ tudi $\mathrm{M}$ anajemen $\mathrm{H}$ utan, program $\mathrm{P}$ ascasarjana $\mathrm{U}$ niversitas Patimura, Ambon.

Ashabul, A.,2013. Pendugaan Karbon Bawah Tanah Assessment Of The Below Ground Carbon Program Studi Agroteknologi Fakultas Pertanian. Universitas Syiah Kuala, Darussala - Banda Aceh Indonesia.

Asef, K. Hardjana, Rahimahyuni.,F, Noor'an, Iwan S. Tumakaka., Ahmad Rojikin., 2012. Pendugaan Stok Karbon Kelompok Jenis Tegakan Berdasarkan TipePotensi Hutan. Kawasan Hutan Lindung Sungai Wain. Balai Besar Penelitian Dipterokarpa, Samarinda.

Hairiah, dkk. 2011.Pengukuran Cadangan Karbon: dari tingkat lahan ke bentang lahan. Petunjuk praktis. Edisi kedua. Bogor, World Agroforestry Centre, ICRAF SEA Regional Office, University of Brawijaya (UB), Malang, Indonesia, Bogor.

Indrajaya Y., Cadangan 2013. Karbon Hutan Lindung Long Ketrok Di Kabupaten Malinau, Kalimantan Timur Untuk Mendukung Mekanisme REDD+Balai Penelitian Teknologi Agroforestry. Ciamis. Banjar.

Krisnawati, H, Adinugroho C. W, Imanudin R., 2012., Monograf Model- model Allomertrik Untuk Pendugaan Biomassa Pohon pada Berbagai Tipe Ekosistem Hutan di Indonesia. Kementerian Kehutanan Badan Penelitian dan Pengembangan Konservasi dan Rehabilitasi. Bogor. 
2012., Monograf Model-Model

Allomertrik Untuk Pendugaan Biomassa Dan Stok Karbon Hutan Di Indonesia Peraturan Kepala Badan Penelitian Dan Pengembangan Kehutanan Nomor :P.01/VIII-P3KR/2012. Kementerian Kehutanan Badan Penelitian Dan Pengembangan Konservasi Dan Rehabilitasi. Bogor.

Lugina, dkk.,2011. Prosedur Operasi Standar (SOP) untuk Pengukuran Stok Karbon di Kawasan Konservasi. Pusat Penelitian dan Pengembangan Perubahan Iklim dan Kebijakan Badan Penelitian dan Pengembangan Kehutanan, Kementerian Kehutanan, Indonesia Kerjasama Dengan International Tropical Timber Organization (ITTO), Bogor.

Manuri, dkk.,2011. Teknik Pendugaan Cadangan Karbon Hutan. Merang REDD Pilot Project - German International Cooperation (MRPP-GIZ), Bogor.

Oktavianto B., Basuki W., Sri Wilarso B., 2015. Pendugaan Kandungan Biomassa Dan Karbon Atas Tanah Pada Tegakan Pinus Di Lahan Paska Tambang Silika Holcim Educational Forest. Departemen Silvikultur Fakultas Kehutanan, IPB Bogor.

Rositah, Ratna H., Gusti H., 2012. Pendugaan Biomassa Karbon Serasah Dan Tanah Pada Hutan Tanaman (Shorea Leprosula Miq) Sistem TPTI PT. Suka Jaya Makmur. Fakultas Kehutanan Universitas Tanjung pura. Jalan Imam Bonjol.

Sedjarawan W., Akhbar., Arianingsih I ., 2013.Biomassa Dan Karbon Pohon Di Atas Permukaan Tanah Di Tepi Jalan Taman Nasional Lore Lindu (Studi Kasus Desa Sedoa Kecamatan Lore Utara Kabupaten Poso). Jurusan Kehutanan, Fakultas Kehutanan, Universitas Tadulako. Palu, Sulawesi Tengah.

Selanno F. M., 2014. Studi Pendugaan Model Allometrik Tingkat Permudaan Di Hutan $\mathrm{G}$ unung $\mathrm{L}$ indung $\mathrm{S}$ irimau. J urusan Kehutanan Fakultas Pertanian Universitas Pattimura. Ambon (Skirpsi tidak dipublikasikan).

Siringoringo H. H.., 2013. Potensi Sekuestrasi
Karbon Organik Tanah Pada Pembangunan Hutan Tanaman Acacia mangium Willd. Pusat Litbang Konservasi Dan Rehabilitasi. Bogor. ., 2014. Peranan Penting Pengelolaan Penyerapan Karbon Dalam Tanah Pusat Litbang Konservasi Dan Rehabilitasi. Bogor.

Subekti Rahayu, Betha Lusiana dan Meine Van Noordwijk., 2004. Pendugaan Cadangan Karbon Di Atas Permukaan Tanah Pada Berbagai Sistem Penggunaan Lahan Di Kabupaten Nunukan, Kalimantan Timur.

Sularso, M. 2011. Pendugaan cadangan karbon Di Taman Nasional Meru Betiri. Departemen Konservasi Sumberdaya Hutan Dan Ekowisata Fakultas Kehutanan Institut Pertanian Bogor, Bogor.

Wahyu C. A., Ismed S., Mardi T.R., Ainal A., Mukhaidil. 2006. Teknik E stimasi Kandungan Karbon Bekas Kebakaran 1997/1998 di PT. Inhutani I. Batu Ampar. Kalimantan Timur. 